\title{
PENGARUH PENGGUNAAN KAPUR PADANG PANJANG SEBAGAI BAHAN PENGISI (FILLER) TERHADAP KARAKTERISTIK CAMPURAN BETON ASPHALT LAPISAN AC-BC (ASPHALT CONCREATE - BINDER COURSE)
}

\author{
Ahmad Refi \\ Jurusan Teknik Sipil, Institut Teknologi Padang \\ refiahmad5@gmail.com \\ DOI: http://dx.doi.org/10.31869/rtj.v2i2.1332
}

\begin{abstract}
Abstrak: Transportasi saat ini telah berkembang menjadi salah satu kebutuhan pokok manusia untuk mewujudkan kondisi jalan yang berkualitas maka perlu diberikan lapisan tambah antara tanah dan roda kendaraan berupa lapisan perkerasan. Pada penelitian ini penulis mencoba untuk mengetahui seberapa besar pengaruh penggunaan kapur Padang Panjang sebagai filler pada campuran panas agregat (AC-BC) dengan perbandingan material abu batu, dimana kapur menggandung kalsium karbonat yang biasanya juga bisa digunakan untuk material konstruksi.Penelitian ini mengkaji tentang variasi campuran kapur abu batu $100 \%$ - kapur $0 \%$, abu batu $75 \%$ - kapur $25 \%$, abu batu $50 \%$ - kapur $50 \%$, abu batu $25 \%$ - kapur $75 \%$ terhadap campuran aspal panas $A C-B C$ dengan kapur sebagai bahan pengisi pada uji Marshall. Kadar Aspal yang digunakan adalah 4.5\%,5.0\%, 5.5\%,6.0\% dan $6.5 \%$, dimana aspal yang digunakan adalah aspal pen 60/70 dan masing-masing campuran dibuat tiga benda uji. Metoda yang digunakan pada pengujian ini adalah dengan pengujian Marshall Test. Dalam penelitian ini diketahui bahwa dengan penambahan filler abu batu 100\% - kapur 0\% dapat memenuhi semua spesifikasi marshall berupa nilai kepadatan (Density), Stabilitas, Rongga dalam agregat (Void In Mineral Aggregate), Rongga Dalam Campuran (Void In The Mix), Rongga Dalam Campuran Asphal (Void Fillet With Asphalt), Kelelehan Plastis (Flow), Hasil Bagi Marshall (Marshall Quotient) dengan KAO 5.945\%, pada pemakaian abu batu 75\% - kapur 25\% juga memenuhi semua spesifikasi marshall dengan KAO 6.225\% , Namun pada pemakaian abu batu 50\% - kapur 50\% dan abu batu $25 \%$ - kapur $75 \%$ tidak memenuhi spesifikasi marshall, sehingga persentase tersebut tidak baik digunakan pada campuran aspal panas $\mathrm{AC}-\mathrm{BC}$.
\end{abstract}

Kata Kunci : Kapur Padang Panjang, Filler, Aspal Panas AC-BC, Spesifikasi Marshall.

\section{PENDAHULUAN}

Transportasi saat ini telah berkembang menjadi salah satu kebutuhan pokok manusia. Berdasarkan UU RI No 38 Tahun 2004 tentang Jalan mendefinisikan "jalan adalah prasarana transportasi darat yang meliputi segala bagian jalan, termasuk bangunan pelengkap dan perlengkapannya yang diperuntukkan bagi lalu lintas, yang berada pada permukaan tanah, di atas permukaan tanah, di bawah permukaan tanah dan/atau air, serta di atas permukaan air, kecuali jalan kereta api, jalan lori, dan jalan kabel". Sedangkan berdasarkan UU RI No 22 Tahun 2009 tentang Lalu lintas dan Angkutan Jalan yang diundangkan setelah UU No 38 mendefinisikan "jalan adalah seluruh bagian jalan, termasuk bangunan pelengkap dan perlengkapannya yang diperuntukkan bagi Lalu lintas umum, yang berada pada permukaan tanah, diatas permukaan tanah, di bawah permukaaan tanah dan/atau air, serta di atas permukaan air, kecuali jalan rel dan jalan kabel".

Untuk mewujudkan kondisi jalan yang berkualitas maka perlu diberikan lapisan tambah antara tanah dan roda kendaraan berupa lapisan perkerasan. Salah satu jenis lapisan perkerasan tersebut adalah lapisan ACBC (Asphalt Concrete-Binder Course). Lapisan ini merupakan lapisan perkerasan yang terletak dibawah lapisan aus (Wearing Course) dan di atas lapisan pondasi (Base Course). Lapisan ini tidak berhubungan langsung dengan cuaca, tetapi harus mempunyai ketebalan dan kekakuan yang cukup untuk mengurangi tegangan/regangan akibat beban lalu lintas yang akan diteruskan ke lapisan di bawahnya yaitu Base dan Sub Grade (Tanah Dasar). Untuk mendapatkan lapisan AC-BC yang berkualitas maka dibutuhkan material material penyusun yang baik dan juga berkualitas. Salah satu material penyusun lapis $\mathrm{AC}-\mathrm{BC}$ adalah filler sebagai bahan pengisinya.

$\begin{array}{lr}\text { Fakultas Teknik UMSB } & \text { ISSN 2599-2081 } \\ \text { EISSN 2599-2090 }\end{array}$


Dimana sebagai bahan penggisi biasanya menggunakan abu batu. Namun terdapat bahan lain yang dapat digunakan dalam campuran Asphalt Concrete yaitu kapur padam (hydrated lime). Secara umum kapur bersifat hidrolis, tidak menunjukkan pelapukan dan dapat terbawa arus. Secara fisik kapur merupakan batuan sedimen yang terdiri dari mineral "Calsium Carbonat" $\left(\mathrm{CaCO}_{3}\right)$ yang kemudian melalui pembakaran dengan suhu tinggi lalu disiram dengan air sehingga menghasilkan kapur padam "Calsium Hydroksida" $\left(\mathrm{Ca}(\mathrm{OH})_{2}\right)$. Berdasarkan uraian latar belakang diatas maka penulis bermaksud melakukan penelitian mengenai : "Pengaruh Penggunaan Kapur Padang Panjang Sebagai Bahan Pengisi (Filler) Terhadap Karakteristik Campuran Beton Asphalt Lapisan ACBC (Asphalt Concrete-Binder Course)".

\section{METODA PENELITIAN}

Bagan alir penelitian dipaparkan pada Gambar 1.

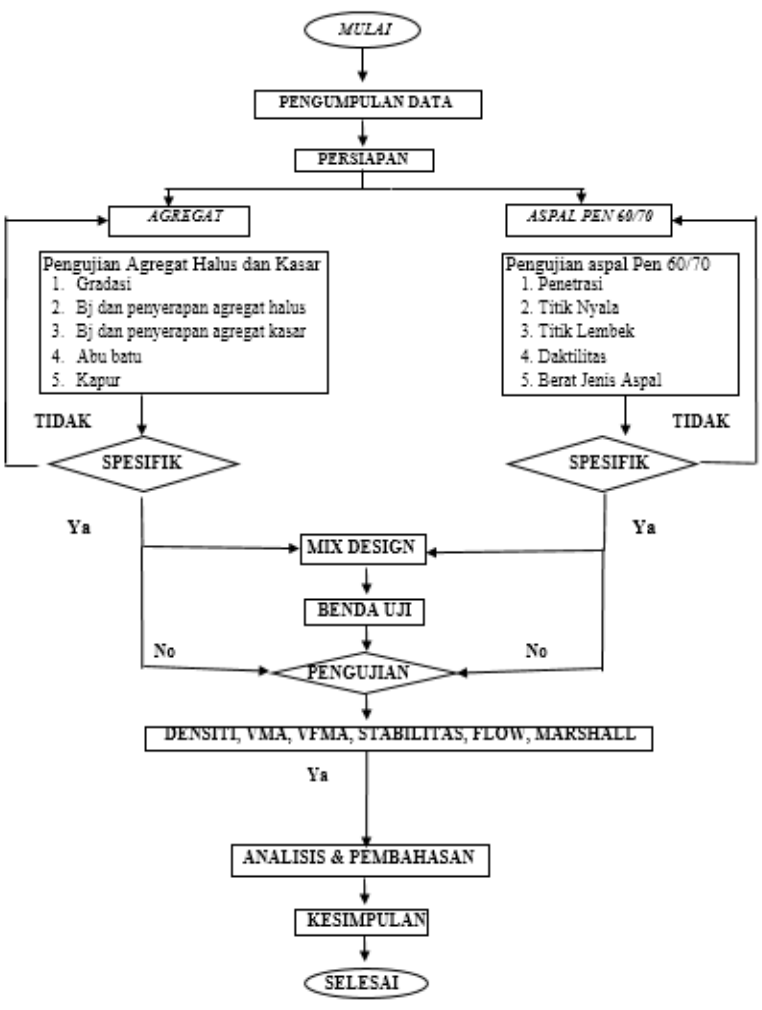

Gambar 1. Bagan alir pelaksanaan penelitian

\section{ANALISA DAN PENGOLAHAN DATA \\ Presentasi Data}

Hasil pemeriksaan yang telah dilakukan di Laboratorium Teknik Sipil Politeknik Negeri Padang terhadap aspal, aggregat kasar dan aggregat halus maka didapatkan sifat-sifat bahan yang digunakan telah memenuhi persyaratan Spesifikasi Bina Marga (2010) seperti tabel 1 berikut :

Tabel 1 Hasil pemeriksaan karakteristik Aspal Penetrasi 60/70

\begin{tabular}{|c|l|c|r|}
\hline No & \multicolumn{1}{|c|}{ Pengujian } & \multicolumn{1}{|c|}{$\begin{array}{c}\text { Standart SNI } \\
\mathbf{2 0 1 0} \text { Rev 3 }\end{array}$} & $\begin{array}{c}\text { Hasil } \\
\text { Pengujian }\end{array}$ \\
\hline & $\begin{array}{l}\text { Penetrasi pada } \\
25{ }^{\circ} \mathrm{C}(0,1 \\
\text { mm })\end{array}$ & $60-70$ & 60 \\
\hline 2 & $\begin{array}{l}\text { Titik Lembek } \\
{ }^{\circ} \mathrm{C}\end{array}$ & $\geq 48$ & 48,5 \\
\hline 3 & Titik Nyala ${ }^{\circ} \mathrm{C}$ & $\geq 232$ & 338 \\
\hline 4 & $\begin{array}{l}\text { Daktilitas 25 } \\
{ }^{\circ} \mathrm{C}\end{array}$ & $\geq 100$ & $>100$ \\
\hline 5 & $\begin{array}{l}\text { Berat Jenis } \\
\text { Aspal }\end{array}$ & $\geq 1$ & 1,04 \\
\hline
\end{tabular}

(Sumber : Hasil Penelitian)

Hasil pengujian aggregat kasar dan aggregat halus dan filler dapat dilihat pada tabel berikut ini :

Tabel 2 Pemeriksaan Karakteristik Agregat Kasar, Halus dan Filler

\begin{tabular}{|r|l|r|r|}
\hline No & \multicolumn{1}{|c|}{ Pengujian } & \multicolumn{1}{c|}{$\begin{array}{c}\text { Standart } \\
\text { SNI }\end{array}$} & $\begin{array}{c}\text { Hasil } \\
\text { Pengujian }\end{array}$ \\
\hline & $\begin{array}{l}\text { Berat Jenis dan } \\
\text { Penyerapan } \\
\text { Aggregat Kasar }\end{array}$ & $2,2-2,7$ & \\
\hline & ( Bj Bulk ) & & 2,556 \\
\hline & ( Bj SSD ) & & 2,623 \\
\hline & ( Bj semu ) & & 2,74 \\
\hline & Penyerapan & $<3$ & 2,62 \\
\hline & $\begin{array}{l}\text { Berat Jenis dan } \\
\text { Penyerapan } \\
2\end{array}$ & & \\
\hline & Aggregat Halus & $2,2-2,7$ & \\
\hline & ( Bj Bulk ) & & 2,53 \\
\hline & ( Bj SSD ) & & 2,598 \\
\hline & ( Bj semu ) & & 2,716 \\
\hline 3 & Penyerapan & & 2,7 \\
\hline 3 & Berat Jenis & Filler & 2,595 \\
\hline 4 & $\begin{array}{l}\text { Berat Jenis } \\
\text { Kapur }\end{array}$ & & 2,03 \\
\hline
\end{tabular}

(Sumber : Hasil Penelitian ) 

Sedangkan untuk gradasi campuran yang
digunakan pada lapisan AC-BC hasil pengujiannya dapat ditampilkan pada tabel berikut ini :

Tabel 3 Hasil Pemeriksaan Gradasi Campuran AC-BC

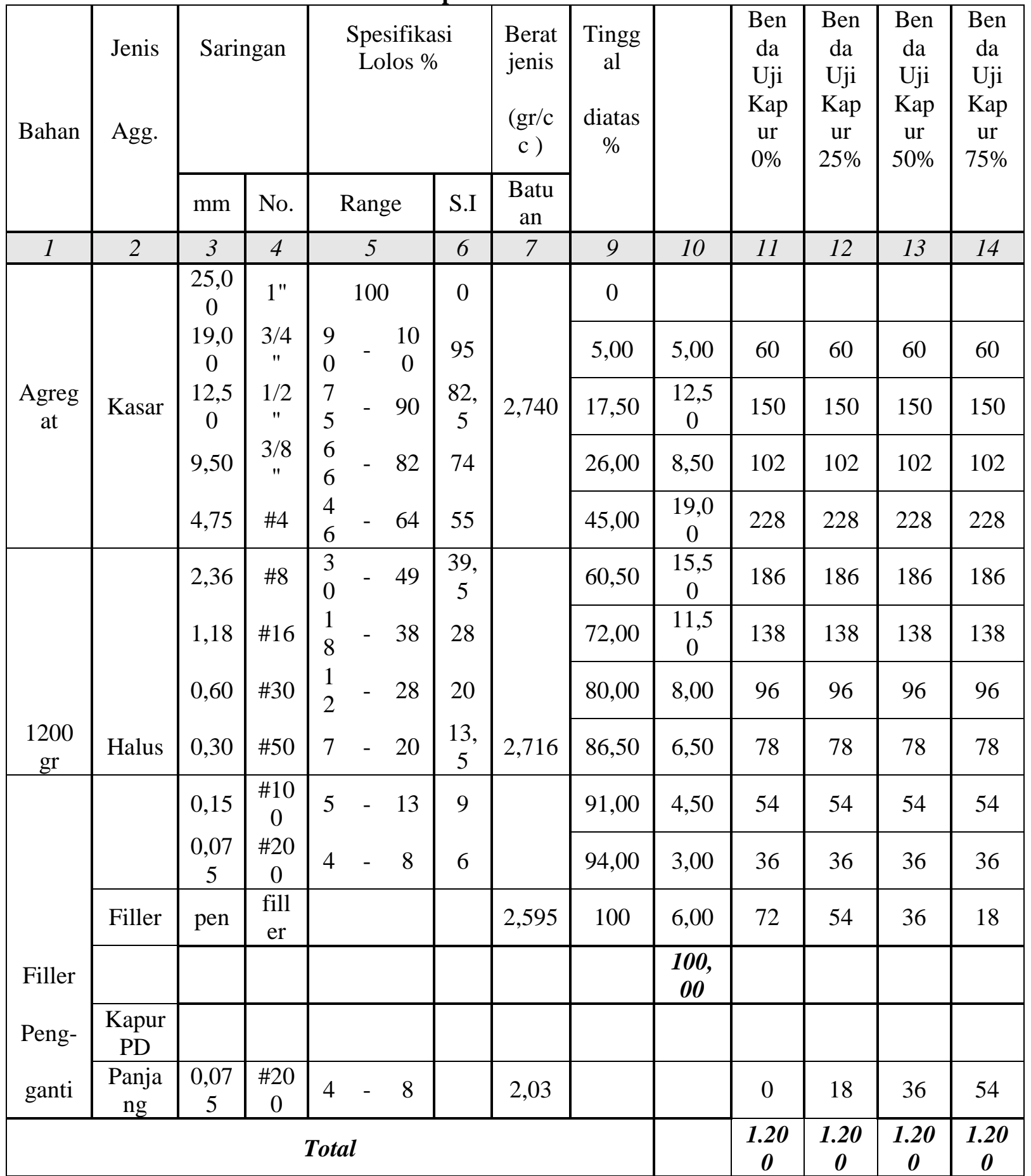

(Sumber : Hasil Penelitian )

\section{Pembahasan}

Semua hasil pemeriksaan terhadap aspal, aggregat kasar dan aggregat halus telah memenuhi spesifikasi Bina Marga 2010 Revisi 3 Divisi 6.
Karakteristik Marshall Campuran Beton AC

Karakteristik Marshall Campuran Beton Aspal AC yaitu: kepadatan (Density), Stabilitas, 
Rongga dalam agregat (Void In Mineral Aggregate), Rongga Dalam Campuran (Void In The Mix), Rongga Dalam Campuran Asphal (Void Fillet With Asphalt), Kelelehan Plastis (Flow), Hasil Bagi Marshall (Marshall Quotient).

\section{Kepadatan}

Nilai density adalah nilai berat volume untuk menunjukkan kepadatan dari campuran beton aspal. Faktor-faktor yang mempengaruhi density yaitu temperatur pemadatan, komposisi bahan penyusun. Semakin bertambah kadar aspal semakin banyak rongga-rongga udara terisi aspal, sehingga kerapatan semakin tinggi. Hubungan antara Kadar Aspal dan Density dengan penambahan Kapur dapat dilihat pada Gambar 3 berikut ini :
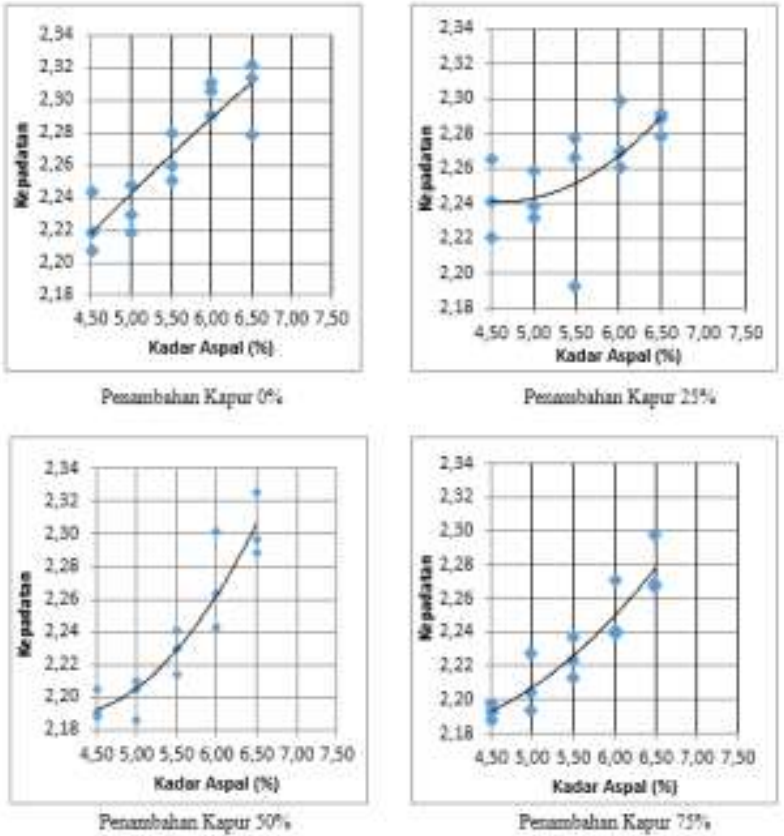

\section{Gambar 2 : Hubungan Antara Kadar Aspal dan Kepadatan Pada Penambahan Filler Kapur (Sumber : Hasil Penelitian)}

Gambar 2 menunjukkan bahwa nilai density (kepadatan) yang didapat dari hasil pengujian dalam campuran beton aspal dengan pemakaian kadar aspal 4.5\%-6.5\% dan penambahan kapur, dengan variasi yaitu $0 \%, 25 \%, 50 \%, 75 \%$ terlihat bahwa dengan penambahan kapur $0 \%$ nilai density (kepadatan) semakin bertambah seiring dilakukan penambahan kadar aspal dari $4.5 \%$ sampai $6.5 \%$ berupa grafik lurus yang mendaki secara beraturan. Pada penambahan filler kapur $25 \%$ seiring dilakukan penambahan kadar aspal terjadi penambahan nilai density namun nilainya lebih rendah dari campuran tanpa penambahan filler kapur, grafik yang dihasilkan berupa grafik lengkung hal ini terjadi karena masing-masing benda uji nilai kepadatannya mengalami penurunan karena pengaruh penambahan filler kapur, namun nilai density terus mengalami penambahan seiring dilakukan penambahan kadar aspal. Pada penambahan kapur 50\% juga terbentuk garis lengkung dimana seiring dilakukan penambahan kadar aspal maka nilai density (kepadatan) juga mengalami peningkatan. Dan nilai density (kepadatan) juga lebih rendah dibandingkan dengan campuran tanpa filler kapur. Untuk campuran yang terakhir yaitu penambahan filler kapur $75 \%$ terlihat seiring dilakukan penambahan kadar aspal maka nilai density (kepadatan) juga mengalami kenaikan namun nilainya lebih rendah dari campuran dengan penambahan filler kapur $25 \%$ hal ini terjadi karena campuran banyak mengandung filler kapur. Jadi semakin banyak kadar filler kapur yang digunakan dalam campuran maka nilai density (kepadatan)nya semakin mengalami penurunan hal ini terjadi karena sifat dari kapur yang memiliki daya serap lebih tinggi dibandingkan dengan abu batu, kadar aspal yang seharusnya bisa jadi perekat dan masuk diantara butiran menjadi berkurang, karena telah diserap kapur, hal ini menyebabkan kurang padatnya campuran yang menggunakan kapur sebagai filler.

\section{Void in mineral Agregat (VMA)}

Void in mineral Agregat (VMA) merupakan rongga udara antara butiran agregat yaitu rongga udara yang ada diantara partikel campuran agregat campuran aspal yang sudah dipadatkan termasuk ruang yang terisi aspal yang dinyatakan dalam persen terhadap total volume campuran aspal agregat. Faktor-faktor yang mempengaruhi void in maneral Agregat antara lain gradasi agregat (komposisi campuran aggregat dan ukuran diameter butir terbesar), energi pemadat, kadar aspal, dan bentuk butiran. Pada Gambar 4.2 berikut ini dapat dilihat perbandingan antara pemakaian kadar aspal 4.5\%-6.5\% dan penambahan kapur, dengan variasi yaitu $0 \%, 25 \%, 50 \%$, $75 \%$ yang mempengaruhi pada nilai VMA. Hubungan antara Kadar Aspal dan VMA 
dengan penambahan Kapur dapat dilihat pada Gambar 3 berikut ini :

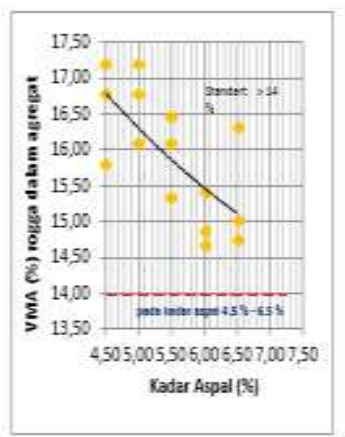

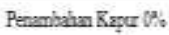

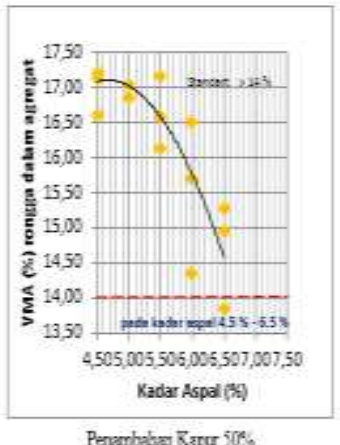

Penembahar Karfu 50\%

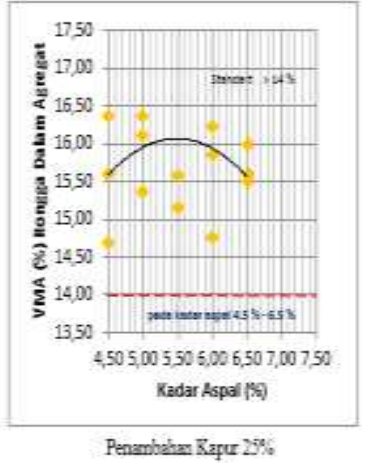

Penambahan Rasur 20

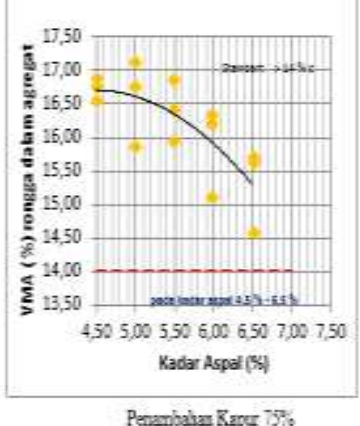

Gambar 3 : Hubungan Antara Kadar Aspal dan VMA Pada Penambahan Filler Kapur (Sumber : Hasil Penelitian)

Gambar 3 menunjukkan kondisi akibat penambahan kapur dengan pamakaian kadar aspal penetrasi 60/70 terhadap rongga antar butir Aggregat (VMA) dari 3 (tiga) jenis penambahan filler yang telah dilakukan dalam penelitian. Pada dasarnya perbedaan antara filler yang dipakai tersebut tidaklah teratur pada keadaan kadar aspal yang sama, seperti yang dapat kita perhatikan pada Gambar 4.2 bahwa penambahan filler kapur 0\% seiring dilakukan penambahan kadar aspal maka nilai VMA mengalami penurunan secara teratur. Nilai VMA terendah terjadi pada kadar aspal $6.5 \%$ dan memenuhi spesifikasi Bina Marga 2010 Divisi 3 Revisi 6 yaitu >14\% sampai $17 \%$. Pada penambahan kapur $25 \%$ nilai VMA yang diperoleh tidak beraturan seiring dilakukan penambahan kadar aspal, dan ditunjukkan dengan grafik melengkung yang awalnya rendah kemudian naik dan akhirnya mengalami penurunan kembali semua benda uji memasuki range yang disyaratkan oleh Bina Marga 2010 Divisi 3 Revisi 6. Nilai VMA terendah pada penambahan kadar filler kapur $25 \%$ ini pada penambahan kadar aspal 6.5\%. Dibandingkan dengan tanpa menggunakan penambahan campuran filler kapur nilai VMA penambahan kapur 25\% lebih tinggi pada penambahan kadar aspal $6.5 \%$, dan nilai VMA tertinggi pada kadar aspal $5.5 \%$. Pada penamabahsn filler kapur $50 \%$ terlihat bahwa seiring dilakukan penambahan kadar aspal maka nilai VMA mengalami penurunan. Namun masing-masing benda uji mengalami kenaikan nilai VMA saat dibandingkan dengan benda uji tanpa menggunakan filler kapur dan lebih banyak benda uji yang memasuki spesifikasi $>14 \%$ dan $<17 \%$ sesuai persyaratan Bina Marga 2010 Divisi 6 Revisi 3. Campuran terakhir yaitu penambahan filler kapur $75 \%$, terlihat setiap benda uji mengalami kenaikan nilai VMA dibandingkan dengan penambahan filler $50 \%$. Seiring dilakukan penambahan kadar aspal nilai VMA mengalami penurunan secara bertahap. Hal ini memperlihatkan penambahan kadar apal akan mengisi rongga antar agregat, menurunnya nilai VMA ini disebabkan rongga antar butiran masih cukup besar sehingga penambahan kadar aspal akan mudah masuk kedalam rongga tersebut dengan adanya energi pemadat, sehingga memperkuat ikatan antar agregat serta merapatkan butiran-butiran aggregat dan menyebabkan nilai VMA mengecil. Dari hasil pengujian dapat dilihat bahwa semakin besar penambahan filler kapur, maka semakin tinggi nilai VMA yang dihasilkannya, nilai VMA kapur lebih tinggi dari abu batu hal ini disebabkan karena daya serap kapur lebih tinggi dari abu batu. Sehingga kadar aspal yang seharusnya bisa jadi perekat antar butiran jadi berkurang, karena telah diserap kapur.

\section{Void In The Mix (VIM)}

Void In The Mix (VIM) merupakan persentase rongga dalam campuran. Nilai VIM berpengaruh kepada keawetan dari campuran aspal agregat, semakin tinggi nilai porous, hal ini mengakibatkan campuran menjadi berkurang kerapatannya dimana air dan udara mudah masuk ke rongga-rongga dalam campuran, yang menyebabkan mudah teroksidasi dan mengurangi keawetannya. Pada gambar berikut ini dapat dilihat perbandingan penambahan filler kapur dalam rongga campuran (VIM). Untuk melihat perbandingan pengaruh penambahan filler yang menggunakan beberapa kadar aspal terhadap 
rongga campuran dapat dilihat pada Gambar 4 berikut :
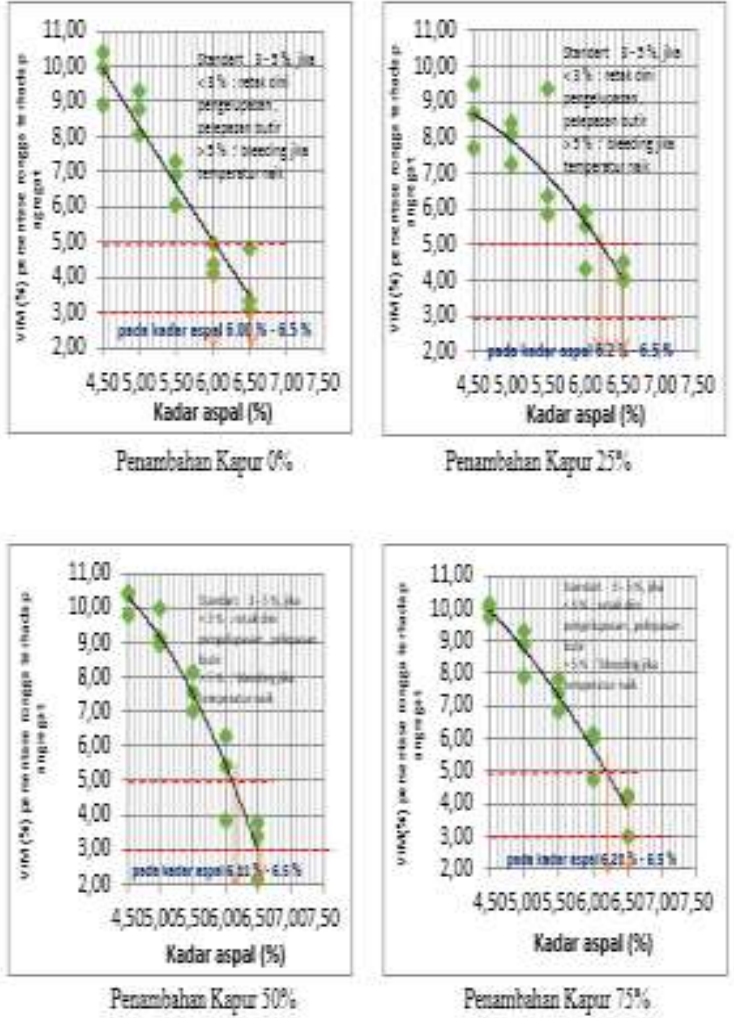

\section{Gambar 4: Hubungan Antara Kadar Aspal dan VIM Pada Penambahan Filler Kapur (Sumber : Hasil Penelitian)}

Berdasarkan Gambar 4 diatas kita bisa melihat variasi penambahan kapur dan jumlah kadar aspal berpengaruh terhadap nilai VIM. Dari gambar dapat dilihat nilai VIM cenderung mengalami penurunan, hal ini terjadi pada semua variasi campuran kapur yang ditinjau. Pada campuran tanpa penambahan filler kapur terlihat semakin tinggi kadar aspal maka nilai VIM semakin menurun, benda uji yang memasuki standar Bina Marga 2010 Divisi 6 Revisi 3 berjumlah 6 buah benda uji. Pada penambahan filler kapur $25 \%$ seiring dilakukan penambahan kadar aspal maka nilai VIM juga mengalami penurunan secara bertahap dan benda uji yang memasuki spesifikasi Bina Marga berjumlah 4 benda uji. Hal ini menunjukkan bahwa dengan penambahan filler kapur jumlah benda uji yang memasuki spesifikasi lebih sedikit dibandingkan dengan tanpa menggunakan filler kapur. Pada penambahan filler kapur $50 \%$ terlihat bahwa seiring dilakukan penambahan kadar aspal maka nilai VIM mengalami penurunan, benda uji yang memasuki spesifikasi Bina Marga berjumlah 3 benda uji. Hal ini menunjukkan bahwa bertambahnya nilai filler kapur benda uji yang memasuki spesifikasi semakin berkurang. Pada penambahan filler kapur $75 \%$ terlihat seiring penambahan kadar aspal nilai VIM juga mengalami penurunan secara bertahap. Benda uji yang memasuki spesifikasi Bina Marga 2010 Divisi 6 Revisi 3 berjumlah 4 benda uji dan jumlahnya lebih kecil dibandingkan dengan benda uji tanpa penambahan filler kapur. Mengecilnya nilai VIM disebabkan setiap penambahan kadar aspal dapat masuk kedalam rongga antar butiran agregat sehingga campuran semakin rapat dan rongga tersisa makin kecil. Jumlah benda uji yang masuk ke dalam persyaratan $3-5 \%$ akibat penambahan filler kapur lebih sedikit dibandingkan dengan benda uji yang hanya menggunakan abu batu, hal ini terjadi karena kadar aspal seharusnya bisa menjadi perekat diantara butiran menjadi berkurang karena telah diserap kapur sehingga membutuhkan kadar aspal yang lebih banyak agar bisa mengisi rongga.

\section{Void Filled With Asphalt (VFA)}

Void Filled With Asphalt (VFA) yaitu rongga terisi aspal pada campuran setelah mengalami pemadatan yang dinyatakan dalam persen campuran setelah mengalami proses pemadatan terhadap rongga butiran aggregat (VMA), sehingga nilai VFA dengan VMA mempunyai kaitan yang erat. Faktor-faktor yang mempengaruhi VFA antara lain kadar aspal, gradasi agregat, energi pemadatan dan temperatur pemadatan. Pada gambar berikut ini dapat dilihat perbandingan penambahan filler kapur terhadap rongga terisi aspal (VFA).
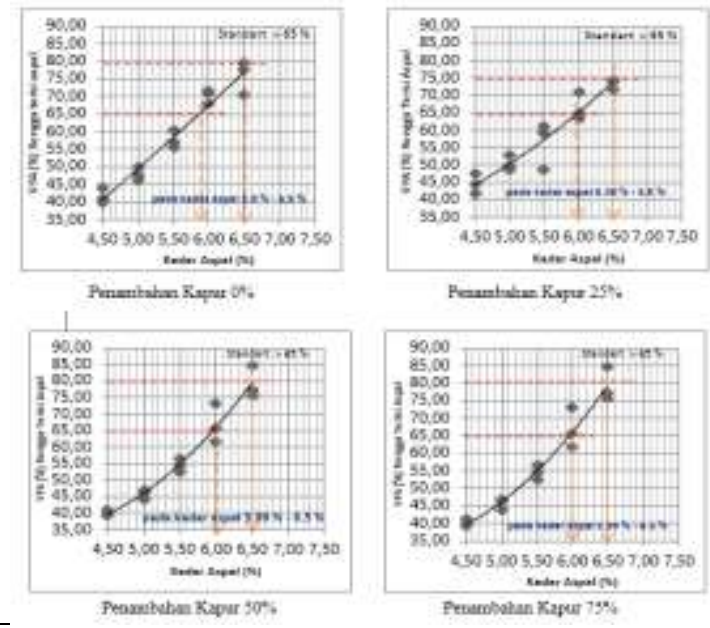

EISSN 2599-2090 
Gambar 5 : Hubungan Antara Kadar Aspal dan VFA Pada Penambahan Filler Kapur (Sumber : Hasil Penelitian)

Gambar 5 memperlihatkan pada setiap penambahan filler kapur dan penambahan kadar aspal pada campuran cenderung menunjukkan kenaikan, hal ini disebabkan oleh setiap penambahan kadar aspal, rongga antar butiran aggregat masih cukup besar dan dapat menampung aspal yang masuk. Pada campuran tanpa penambahan filler kapur terlihat semakin naik kadar aspal yang diberikan menyebabkan bertambahnya nilai VFA secara beraturan, Berdasarkan spesifikasi Bina Marga 2010 Devisi 6 Revisi 3 standar baik untuk campuran memiliki nilai VFA > 65\%. Pada grafik tanpa penambahan filler kapur benda uji yang memenuhi berjumlah 6 benda uji pada kadar aspal $5.9 \%$ sampai $6.5 \%$. Penambahan filler kapur 25\% menunjukkan semakin tinggi kadar aspal yang diberikan dapat menaikkan nilai VFA, benda uji yang memasuki standar yang ditetapkan Bina Marga yaitu benda uji dengan kadar aspal $6.0 \%$ sampai $6.5 \%$ berjumlah 5 buah benda uji. Pada penambahan filler kapur $50 \%$ dan $75 \%$ juga semakin tinggi kadar aspal yang diberikan maka dapat menaikkan nilai VFA benda uji yang memenuhi spesifikasi yaitu benda uji yang mengandung kadar aspal $5.99 \%$ sampai $6.5 \%$ berjumlah 4 benda uji. Jadi dengan penambahan filler kapur maka nilai VFA benda uji yang memasuki spesifikasi menjadi lebih berkurang dibandingkan dengan campuran tanpa menggunakan filler kapur dan kadar aspal yang digunakan lebih banyak dibandingkan tanpa menggunakan filler kapur hal ini terjadi karena semakin banyak aspal yang menyelimuti anggregat, maka semakin besar rongga yang terisi aspal.

\section{Stabilitas}

Stabilitas merupakan kemampuan lapis perkerasan menerima beban lalu lintas tanpa mengalami perubahan bentuk tetap seperti gelombang alur (rutting), maupun mengalami bledding. Nilai stabilitas dipengaruhi oleh kohesi/penetrasi, kadar aspal, gesekan (Internal Friction), sifat saling mengunci (interlocking) dari partikel partikel aggregat, bentuk tekstur permukaan serta gradasi aggregat. Pada gambar berikut ini dapat dilihat perbandingan hubungan antara pemakaian kadar aspal terhadap stabilitas dimana dilakukan penambahan kapur sebagai bahan pengganti filler. Hubungan antara Kadar Aspal dan stabilitas dengan penambahan Kapur dapat dilihat pada 6 berikut ini :
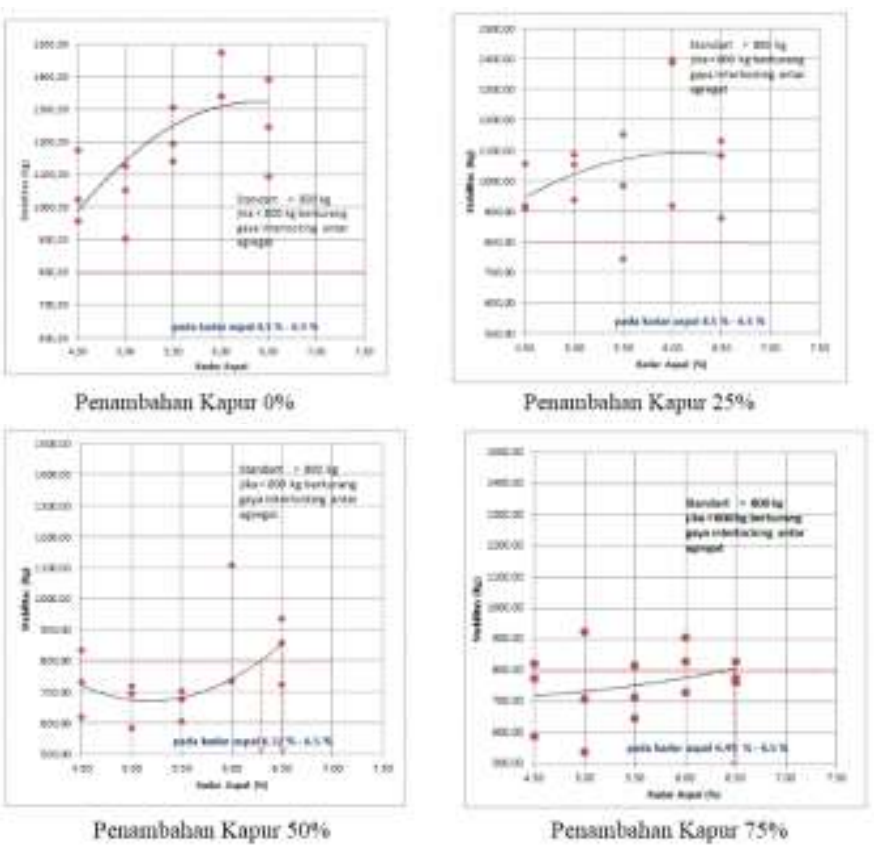

\section{Gambar 6 : Hubungan Antara Kadar Aspal dan Stabilitas Pada Penambahan Filler Kapur (Sumber : Hasil Penelitian)}

Gambar 6 dengan menggunakan persentase campuran aggregat yang sama pada pemakaian penambahan filler kapur, menunjukkan nilai stabilitas pada campuran AC-BC cukup bervariasi, pada penambahan filer kapur 0\% menunjukkan peningkatan nilai stabilitas seiring dilakukan penambahan kadar aspalnya dan semua benda uji memenuhi spesifikasi Bina Marga Divisi 6 Revisi 3 mengenai stabilitas yaitu > $800 \mathrm{~kg}$. Pada penambahan filler kapur $25 \%$ terlihat seiring dilakukan penambahan kadar aspal maka nilai stabilitas makin tinggi namun dibandingkan dengan tanpa menggunakan filler kapur nilai stabilitas menggunakan filler kapur jauh lebih tinggi dibandingkan penambahan kapur 25\% dan semua benda uji memenuhi spesifikasi Bina Marga. Penambahan filler kapur 50\% menunjukkan benda uji mengalami variasi yang awalnya benda uji dengan kadar aspal $4.5 \%$ mengalami penurunan namun diakhir pada penambahan kadar aspal $6.5 \%$ mengalami kenaikan, namun benda uji tidak memenuhi spesifikasi Bina Marga $<800 \mathrm{~kg}$ hanya pada kadar aspal $6.5 \%$ yang > $800 \mathrm{~kg}$. Pada penambahan filler kapur $75 \%$ menunjukkan
$174 \quad$ Fakultas Teknik UMSB 
semua benda uji tidak memenuhi spesifikasi Bina Marga $<800 \mathrm{~kg}$. Turunnya nilai stabilitas disebabkan oleh rongga yang tidak di isi oleh aspal yang menyebabkan aspalnya hanya sebagai pelicin yang pada akhirnya menurunkan nilai stabilitas. Jika dibandingkan nilai stabilitas campuran dengan filler abu batu dengan stabilitas nilai campuran dengan filler kapur, campuran dengan filler kapur jauh lebih rendah dari pada nilai stabilitas campuran dengan filler abu batu dan tidak memnuhi spesifikasi Bina Marga, semakin banyak filler menurunkan nilai stabilitas campuran.

\section{Flow (Kelelehan)}

Flow (kelelehan) adalah deformasi vertikal yang terjadi mulai dari awal pembebanan sampai dengan kondisi stabilitas menurun, yang menunjukkan besarnya deformasi yang terjadi pada lapisan perkerasan akibat menahan beban yang diterimanya. Pengujian dengan alat marshall fow (kelelehan) merupakan besarnya perubahan bentuk plastis suatu benda uji campuran agregat yang terjadi akibat pembebanan yang dilakukan sampai batas keruntuhan, dinyatakan dalam panjang. Nilai flow dipengaruhi oleh kadar aspal, viskositas aspal, gradasi agregat, jumlah dan temperatur pemadatan. Campuran aspal agregat yang mempunyai angka kelelehan rendah dengan stabilitas tinggi menjadi kaku, cenderung plastis dan mudah berubah bentuk bila mendapat beban lalu lintas. Pada grafik dapat dilihat hubungan pemakaian kadar aspal dan nilai flow akibat penambahan kapur sebagai bahan pengisi filler. Hubungan antara Kadar Aspal dan Flow dengan penambahan Kapur dapat dilihat pada Gambar 7 berikut ini : kapur yang ditambahkan maka semakin
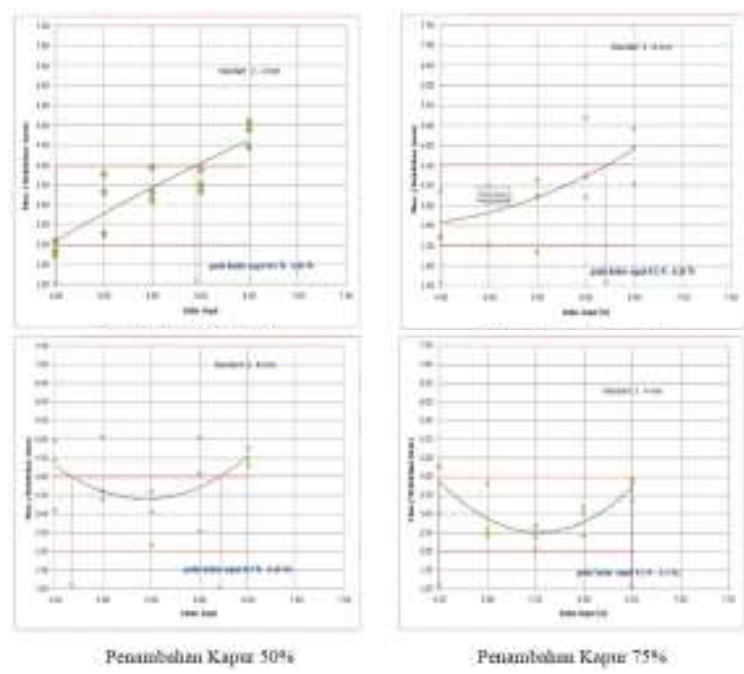

\section{Gambar 7 : Hubungan Antara Kadar Aspal dan Kelelehan (Flow) Pada Penambahan Filler Kapur (Sumber : Hasil Penelitian)}

Gambar 7 memperlihatkan nilai kelelehan (Flow) pada pemakaian kadar aspal pen 60/70 terhadap 3 (tiga) jenis penambahan filler kapur, pada gambar ini dapat kita lihat pada campuran tanpa filler kapur nilai flow mengalami kenaikkan seiring dilakukan penambahan kadar aspal campuran yang memenuhi spesifikasi Bina Marga 2010 Divisi 6 Revisi 3 yaitu 3\% $4 \%$ adalah benda uji yang menggandung kadar aspal $4.5 \%$ sampai $5.95 \%$. Penambahan filler kapur 25\% menunjukkan kenaikkan nilai kelelehan (flow) seiring dilakukan penambahan kadar aspal, benda uji yang memenuhi spesifikasi yaitu yang menggandung kadar aspal $4.5 \%$ sampai $6.25 \%$. Hal ini menunjukkan dengan melakukan penambahan filler kapur maka kadar aspal yang di butuhkan semakin meningkat. Pada penambahan kadar aspal $50 \%$ terlihat penambahan filler kapur yang awalnya memenuhi spesifikasi namun kemudian seiring dilakukan penambahan kadar aspal mengalami penurunan sampai kadar aspal 5.5\% kemudian mengalami kenaikan kembali sampai kadar aspal 6.5\%. Benda uji pada penambahan filler $50 \%$ hanya pada kadar aspal $4.5 \%$ dan $6.5 \%$. Penambahan filler kapur $75 \%$ menunjukkan semua benda uji tidak memenuhi spesifikasi Bima Marga 2010 Divisi 6 berupa grafik parabola. Dibandingkan dengan benda uji tanpa menggunakan filler kapur nilai kelelehan lebih tinggi namun karena penambahan filler kapur benda uji 
menghasilkan nilai kelelehan yang mengalami penurunan seiring dilakukan penambahan filler kapur. Penurunan nilai flow diakibatkan oleh banyaknya rongga aggregat yang tidak terisi aspal. Dari gambar juga dapat disimpulkan bahwa dengan penggunaan filler kapur pada campuran, maka nilai flow akan semakin rendah dan semua benda uji tidak memenuhi spesifikasi nilai yaitu 2-4 $\mathrm{mm}$.

\section{Marshall Quotient (MQ)}

Marshall Quotient (MQ) merupakan hasil bagi marshall dengan flow. Nilai flow mengambarkan nilai-nilai fleksibilitas dari campuran. Semakin besar nilai MQ berarti campuran semakin kaku dan sebaliknya semakin kecil nilai MQ maka campuran semakin lentur. Faktor-faktor yang mempengaruhi hasil bagi marshall yaitu nilai stability dan flow, penetrasi, viskositas aspal, kadar aspal acmpuran, bentuk dan tekstur permukaan agregat. Pada gambar berikut ini dapat dilihat hubungan antara penambahan kapur sebagai bahan pengganti filler dengan kadar aspal terhadap nilai MQ (Marshall Quotient). Hubungan antara Kadar Aspal dan stabilitas dengan penambahan Kapur dapat dilihat pada Gambar 8 berikut ini :

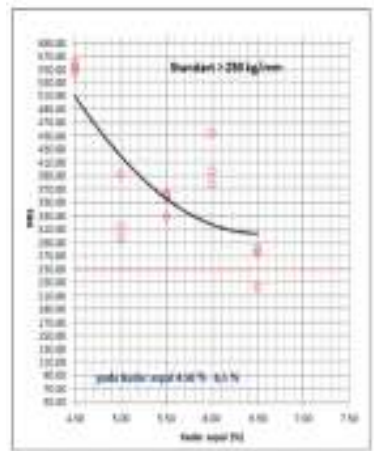

Pemubalan Kapur 0\%

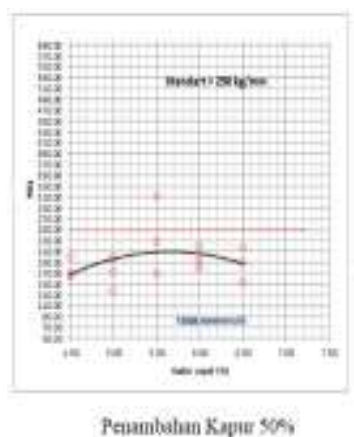

Peambahan Kavie Sos;

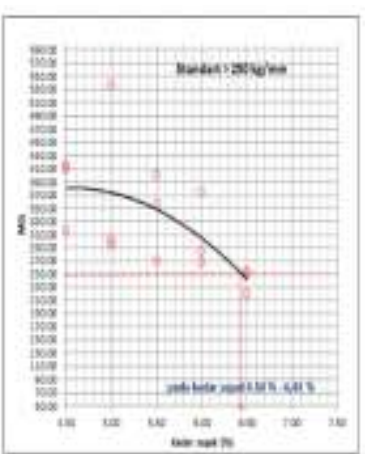

Peunahalau Kapu 254

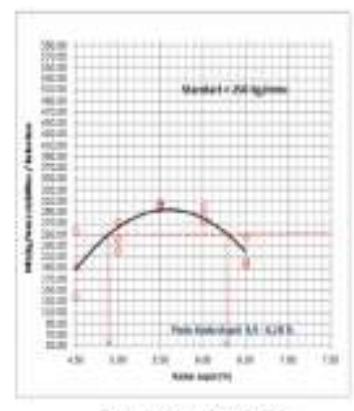

Penaubehan Kegar 799.

\section{Gambar 8 : Hubungan Antara Kadar Aspal dan MQ Pada Penambahan Filler Kapur}

(Sumber : Hasil Penelitian)

Gambar 8 tersebut menunjukkan bahwa variasi penambahan filler kapur mempengaruhi nilai MQ walaupun cenderung turun dan menghasilkan grafik yang bervariasi. Pada penggunaan filler kapur $0 \%$ terlihat nilai $\mathrm{MQ}$ mengalami penurunan seiring dilakukan penambahan kadar aspal dan semua benda uji memenuhi spesifikasi Bina Marga 2010 Divisi 6 Revisi 3 yaitu > $250 \mathrm{~kg} / \mathrm{mm}$. Penambahan filler kapur $25 \%$ menunjukkan nilai MQ jauh menunjukkan penurunan mulai dari kadar aspal $4.5 \%$ sampai $6.5 \%$ seiring dilakukan penambahan kadar aspal maka nilai MQ mengalami penurunan dan semua benda uji masuk ke dalam spesifikasi Bina Marga. Penambahan filler kapur 50\% menunjukkan semua benda uji tidak memnuhi spesifikasi Bina marga 2010 namun pada penambahan filler kapur $75 \%$ benda uji yang awalnya kecil kemudia naik hingga kadar aspal 5.5\% tapi kembali menurun sampai kadar aspal 6.5\%. Benda uji yang memnuhi spesifikasi Bina Marga pada penambahan filler kapur $75 \%$ yaitu benda uji yang mengandung kadar aspal $4.9 \%$ sampai $6.28 \%$. Perubahan yang terjadi akibat penambahan kapur cukup bervariasi hal ini disebabkan oleh rongga dalam campuran menjadi kecil, kerapatan campuran meningkat dan kadar aspal tinggi dapat menyebabkan campuran menjadi lebih plastis, jika menerima beban akan mengalami perubahan bentuk (deformasi) yang lebih besar, pemberian kadar aspal yang cukup akan meningkatkan ikatan antar aggregat sehingga membuat campuran menjadi tambah kaku. Dari hasil pengujian nilai MQ kapur lebih rendah dari pada abu batu, dan persentase penambahan filler kapur yang baik yaitu $25 \%$.

\section{Penentuan Kadar Aspal Optimum (KAO)}

Untuk menentukan kadar optimum, nilai-nilai karakteristik Marshall yang terdiri dari: Rongga Antar Butiran Aggregat (void in mineral aggregate / VMA), Rongga Terhadap campuran (Void in The Mix / VITM), Rongga terisi aspal (Void Filled With Asphal / VFM), Stabilitas Kelelehan (Flow), Hasil Bagi Marshall (Marshall Quotion) Nilai-nilai tersebut disesuaikan dengan spesifikasi apakah memenuhi syarat atau tidak. Penentuan Kadar Aspal Optimum dapat dilihat pada tabel berikut ini :
$176 \quad$ Fakultas Teknik UMSB

ISSN 2599-2081

EISSN 2599-2090 

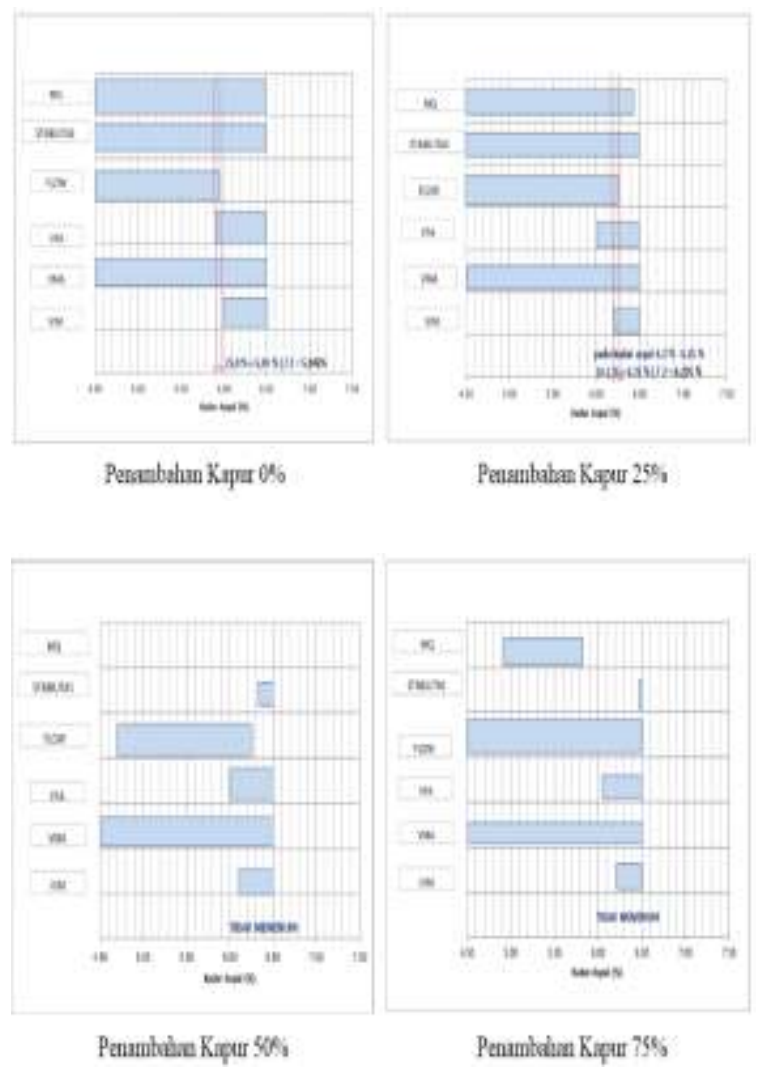

\section{Gambar 9 : Hubungan Antara Kadar Aspal dan KAO Pada Penambahan Filler Kapur \\ (Sumber : Hasil Penelitian)}

Kadar aspal optimum dari filler kapur seperti terlihat pada Gambar 9 tidak semua properties marshall memenuhi spesifikasi yang diisyaratkan, dengan demikian kadar aspal optimum untuk pemakaian kapur yang memenuhi pada penambahan kapur $25 \%$ dengan kadar aspal yaitu $6.2 \%$ - $6.25 \%$ sehingga nilai kadar aspal optimumnya adalah $6.225 \%$. Semua properties marshall yang sebelum memenuhi spesifikasi yang disyaratkan khususnya pada penambahan filler kapur $50 \%$ dan $75 \%$ terjadi karena pada penambahan filler kapur yang mengakibatkan nilai stabilitas yang dihasilkan tidak masuk dalam spesifikasi yang disebabkan oleh tingginya daya serap kapur dari pada abu batu sehingga kadar aspal optimum tidak dapat ditentukan. Pada grafik diatas tidak dapat ditentukan kadar aspal optimum pada penambahan kapur 50\% dan $75 \%$ karena nilai stabilitas dan VIM yang rendah. Rendahnya nilai stabilitas berpengaruh kepada kemampuan aspal untuk melawan deformasi atau perubahan bentuk yang disebabkan beban lalu lintas yang harus dipikul sehingga nilai MQ rendah dan tidak memenuhi spesifikasi yang diisyaratkan.

\section{PENUTUP}

\section{Kesimpulan}

Kegiatan Penelitian ini terasa sangat bermanfaat dan menunjang sekali akan manfaatnya. Berdasarkan pengujian yang telah dilakukan maka penulis dapat menarik kesimpulan bahwa :

1. Campuran tanpa penambahan kapur (abu batu $100 \%$ - Kapur 0\%) memenuhi semua spesifikasi marshall.

2. Penambahan kapur Padang Panjang pada campuran AC-BC mengurangi nilai kepadatan, semakin tinggi kadar kapur yang digunakan maka kepadatan semakin rendah.

3. Nilai VMA (rongga udara antar butiran), VIM (rongga dalam campuran), VFA (rongga terisi aspal) menjadi tidak beraturan dan menurun akibat penambahan kapur Padang Panjang sebagai pengganti filler pada campuran AC-BC.

4. Nilai MQ dan KAO yang memenuhi adalah pada campuran AC-BC tanpa kapur (KAO 5.945\%) dan penambahan kapur 25\% (KAO 6.225\%).

5. Persentase kapur Padang Panjang yang baik digunakan sebagai bahan pengganti filler pada campuran aspal AC-BC adalah $<25 \%$.

\section{Saran}

1. Dilakukan Pengujian lebih lanjut mengenai persentase filler kapur Padang Panjang yang paling cocok untuk dijadikan bahan pengganti filler pada campuran aspal lapis AC-BC sehingga mendapatkan semua nilai properties marshall dan nilai KAO yang memenuhi spesifikasi Bina Marga yang telah ditentukan.

2. Berdasarkan nilai KOA yang telah diperoleh maka dapat dilakukan pengujian lain yaitu pengujian durabilitas aspal untuk mengetahui ketahanan campuran terhadap pengaruh cuaca, air, perubahan temperatur atau keausan akibat gesekan dari kendaraan. 
3. Dalam melakukan pengujian ketelitian pembacaan alat dan prosedur pengujian harus dilakukan dengan hati-hati dan berurutan agar data yang diperoleh lebih akurat.

\section{DAFTAR PUSTAKA}

Handerson Shirley.(2000). "Penuntun Praktis Perencanaan Teknik Jalan Raya". Politeknik Negeri Bandung Jurusan Teknik Sipil.

Kemetrian Pekerjaan Umum dan Perumahan Rakyat, Direktorat Jendral Bina Marga.(2017). "Manual Desain Perkerasan Jalan Revisi Juni 2017'.

Lusyana, dkk. (2013). "Evaluasi Kinerja Campuran Beton Aspal Lapis Aus (AC BC) Memakai Limbah Abu CPO Sebagai Filler". Padang.

Mustan.(2012). "Kajian Variasi Abu Sekam Sebagai Filler Pada Campuram AC-BC dengan Pengujian Marshall”. Padang.

Nofrianto,Hendri. (2013). "Perencanaan Perkersan Jalan Raya". Padang. Kerjasama ITP Padang.

Spesifikasi Umum (revisi 3) Divisi 6.(2010).

Sukirman Silvia.(2003). "Beton Aspal Campuran Panas". Jakarta: Granit.

Suprapto.(2000). "Bahan dan Struktur Jalan Raya”.KMTS FT UGM.

Suryadharma Hendra dan Benidiktus Susanto.(1999). "Rekayasa Jalan Raya". Universitas Atma Jaya Yogyakarta.

Suryana Nyoman,dkk.(2002). "Manual Pekerjaan Campuran Beraspal Panas". Jakarta.

Undang - undang Republik Indonesia no 38. (2004)."Jalan".

Undang - undang Republik Indonesia No 22 .(2009). "Lalu Lintas dan Angkutan Jalan". 